nett' (whom Tully calls, one hardly knows why, Autronius), and Dr. Postgate's own renderings of Dickens and Miss Austen. To say nothing of a Latin Mrs. Bennet, who would have thought that Mr. Alfred Jingle's apologue of Don Bolaro Fizgig and the stomach-pump would go into Latin prose? Yet it does, and reads like a page of Petronius. Any student of enterprise should be tempted by agreeable tours de force like these. In general, of course, the proposed tasks are less exciting, as one would expect. The English passages are very well chosen. They are often difficult, but never without some kind of kinship to Latin which makes them translateable. So many examiners seem to confuse what is legitimately difficult-what can be done, given skill and knowledgewith what really can no more be put into a proper Latin form any more than can a page of Bradshaw or a column of musical criticism! But Dr. Postgate is too old a hand for that.

Another new feature of the book is its Appendix. The first part of this summarises rules given in the Introduction, and illustrates them by reference to the select passages. The second part consists of a series of notes on the passages, showing some of the more important words which a translator should keep in mind. Both sections should be most useful.

A. D. G.

\title{
CORRESPONDENCE
}

\section{ANCIENT TOBOGGANING.}

To the Editors of the CLASSICAL REVIEW. Plutarch, Vita Marii, XXIV. 3.

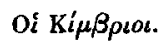

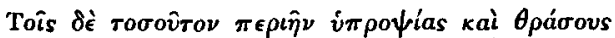

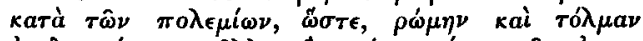

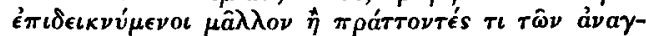

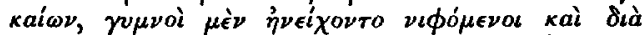

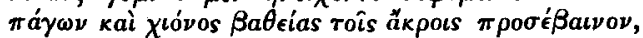

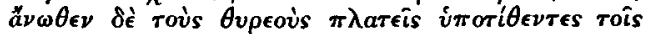

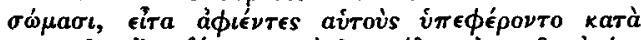

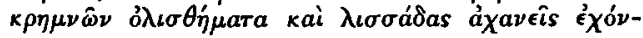
$\tau \omega \nu$.

Might I suggest to the managers of the Public School Alpine Sports that a competition, conducted rigidly under the above conditions, would afford an interesting test for comparing ancient and modern vitality and hardihood?

A. A. CORDNER.

I2, Groswenor Sq., Rathmines, Dublin.

\section{To the Editors of THE CLASSICAL REviEw.}

In reading the Choephoroe, I am puzzled

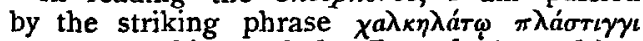
290. Hesychius and the Etymologicum Magnum offer the explanation, which is most usually adopted-viz. $\pi \lambda a ́ \sigma \tau \iota \gamma \xi \dot{\eta} \mu a ́ \sigma \tau \iota \xi$, ảmò rov $\pi \lambda \dot{\eta} \sigma \sigma \epsilon \iota$. This would appear to be a mere conjecture, as the regular meaning of $\pi \lambda a ́ \sigma r i \gamma \xi$ is the 'scale-pan' of a balance, and it is also used by Hippocrates to mean a 'splint' for keeping broken bones in place. This sug-

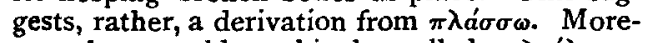
over, how could a whip be called $\chi a \lambda \kappa \dot{\eta} \lambda a r o s$, 'beaten out into metal'? The general signification of $\pi \lambda \dot{\alpha} \sigma \tau \imath \gamma \xi$, especially when coupled with $\chi a \lambda \kappa \dot{n} \lambda a r o s$ seems to be a flat plate of metal. Is it possible, then, that it might have the same meaning as the word 'lamina' in Lucretius (Bk. III. IOI7), "verbera carnifices robur pix lamina taedae,' and refer to the torture of the red-hot plate? I cannot find anything to show that such a torture was familiar to the Greeks, as it must have been to the Romans; cf. Horace, Epistles, I. I 5. 34, 'scilicet ut ventres lamna candente nepotum diceret urendos, correctus Bestius.' But all these tortures were probably Semitic in origin, and it would seem, from the parallel passage in the Eumenides, ll. 186 sqq., that the Erinyes (whose persecutions are being described in this passaye of the Choephoroe) would have been quite at home in an Eastern torture-chamber. It may be an intentional imitation by Lucretius, or a mere coincidence,

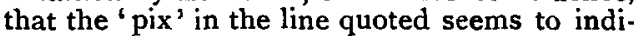

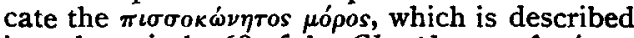
just above in 1.268 of the Choephoroe-Aavóvras

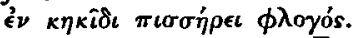

EDWARD J. POWELl.

Magdalen College, Oxford.

\section{To the Editors of the ClassiCal REviEw.}

I am desirous of getting as complete a catena as possible of passages in ancient literature relating to Rome-chiefly the city-illustrating the place it held in the minds and affections of people down the ages. Any quotations will greatly oblige.-Yours faithfully,

$$
\text { William C. Tuting, D.D. }
$$

Sithney Vicarage, Helston, Cornwall. June 27, 1913.

XENOPHON, HELLENICA II. ii. : THE CONSPIRACY OF THE KAAAMHФOPOI.

To the Editors of the CLASSICAL REviEw.

Will you please allow me space to retract my note under the above heading in vol. 
xxvl., p. I86? Professor Campbell Bonner, of the University of Michigan, very kindly points out to me that my suggestion that the $\partial \phi \theta a \lambda \mu \iota \hat{\omega} \nu$ was not a conspirator, but that the

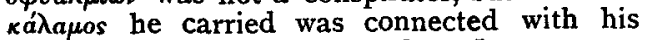
disease, was anticipated by Van Leeuwen on

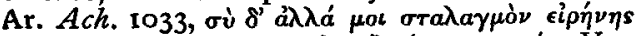

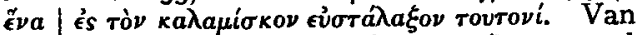

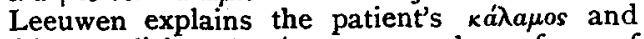
Dicaeopolis's $\kappa a \lambda a \mu i \sigma \kappa o s$ as a cheap form of medicine-phial (cf. the $\nu a ́ \rho \theta \eta \xi$ tinder-box of Prometheus); while the badge of the conspirators he supposes to have been a garland, or at least a sprig of reed worn on the head

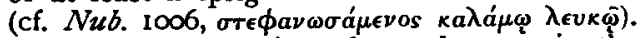
Professor Bonner, in a learned paper in the Transactions of the American Philological Association, vol. xxxix., I909, supports Van Leeuwen

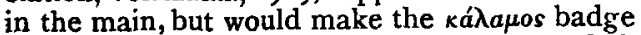
not a garland, but a mere arbitrary symbol, perhaps a baton consisting of a joint or two of reed, and carried in the hand; he gives some very late quotations for the use of short cuttings of reed as tokens. The Professor anticipates but rejects my idea that the ká $\lambda a \mu o s$ was a walking-cane; even if the word can bear that meaning, a walking-cane would be too undistinctive for the badge of a conspiracy. He then gives considerable evidence for $\kappa a ́ \lambda a \mu o s, \kappa a \lambda a-$

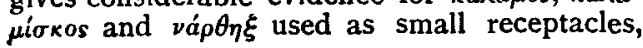

especially for drugs. An interesting passage is Plut. Dem. 29 f., where Demosthenes commits suicide by sucking poison from his reed-pen : 'the кá $\lambda a \mu$ os was probably the original receptacle in which Demosthenes had procured the drug. In order to give the poison-reed the appearance of a harmless pen, it was only necessary to trim and sharpen one end of it.'

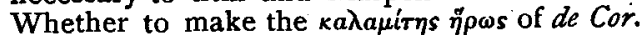
129 'a canonised Dr. Pillbox, a sort of St. Bolus,' and whether to suppose the $\beta i \beta \lambda i o v$ 's

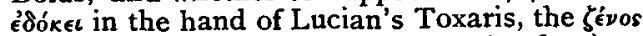
iarpós worshipped at Athens (Luc. Scytha I), to have been really $a \nu a ́ \rho \theta \eta \xi$ of drugs, are questions that the Professor leaves open.-Yours, etc.,

\section{Christ's College, Cambridge.}

$$
\text { H. RACKHAM. }
$$

ON JUVENAL, $S A T$. I. I44.

'Hinc subitae mortes atque intestata senectus.'

To the Editors of the CLASSICAL REviEw.

Mr. D. A. Slater's 'intercepta' (suggested on $\mathrm{p}$. I60 of this volume), though it may give the sense required, seems to me to be lacking in probability. I would read, as being more probable, 'interlecta' (i.e., ' nipped in the bud'), a rare word easily mistakable for 'intestata.' $r=s, l=t, e c=a$ (open).

Samuel Allen.

\section{BOOKS RECEIVED}

Publishers and Authors forwarding books for review are asked to send at the same time a note of the price.

** Excerpts and Extracts from Periodicals and Collections are not included in these Lists unless stated to be separately published.

Amaryllis. Carmen Raphaelis Cariozzari Ferrariensis, in certamine poetico Hoeufftiano promio aureo ornatum. $\operatorname{Io}^{\prime \prime} \times 6 \frac{1}{2}{ }^{\prime \prime}$. Pp. 146. Amsterdam : J. Muller, 1913.

Babelon (E.) Moneta. I I $\frac{1}{2}{ }^{\prime \prime} \times 9^{\prime \prime}$. Pp. 56. Paris : Imprimerie Nationale, I913. Fr. 2.30.

Bidez (J.) Vie de Porphyre: avec les frag-

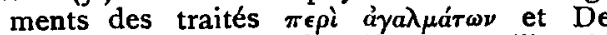
Regressu Animae. $9 \frac{1}{4}^{\prime \prime} \times 64^{\prime \prime}$. Pp. viii +166 +73 .

Briess (E. E.) Le Prétendu IOHMAIOs stPathros. I $d^{\prime \prime} \times 6 \frac{1}{2} "$. Pp. 47-52. Paris : E. Leroux, 1913.

Corpus Scriptorum Ecclesiasticorum Latinorum. Vol. LV. S. Eusebii Hieronymi Opera, (Sect. I., Pars II.). Epistularum, Pars II. Epistulae LXXI.-CXX. Recensuit Isidorus Hilberg. $9 \frac{1}{2} \times 6^{\prime \prime}$. Pp. 516. Leipzig: G. Freytag, 1912. M. 16.

Dorez (L.) Notice sur un Recueil de Poésies Latines, et un Portrait de l'Humaniste Véronais Leonardo Montagna. $11_{\frac{1}{2}}^{\prime \prime} \times 9^{\prime \prime}$. Pp. 34. Paris: Imprimerie Nationale, 1913. Fr. 2.

Map of the Near and Middle East from Rome to Babylon, etc. With ancient and modern names in special character. Mounted on rollers and varnished. $40^{\prime \prime} \times 30^{\prime \prime}$. London : G. W. Bacon and Co., 1913. 6s.

Mochon (E.) Un Décret du Dème de Cholargos relatif aux Thesmophories. $\quad 1 \frac{1^{\prime \prime}}{2} \times 9^{\prime \prime}$. Pp. 24. Paris: Imprimerie Nationale, I913. Fr. I.50.

Riepl (W.) Das Nachrichtenwesen des Altertums, mit besonderer Rücksicht auf die Römer. $9^{\prime \prime} \times 6^{\prime \prime}$. Pp. xiv +478 . Leipzig: B. G. Teubner, 1913. M. 16.

Skoorb (D. R.) In Four Dimensions. $7^{\prime \prime} \times 4 t^{\prime \prime}$. Pp. 64. Leather. Saginaw, Mich., U.S.A. : D. R. Skoorb and Co.

Spohr (L.) Instrumenta Graeca Publica et Privata (Pars Prima). Papyri Jandanae (Fasciculus Tertius). $9 \frac{1}{2}{ }^{\prime \prime} \times 6 \frac{11}{2}$. Pp. 79-123. Leipzig : B. G. Teubner, I913. M. 2.80.

Swindler (Mary H.) Cretan Elements in the Cults and Ritual of Apollo. Bryn Mawr College Monographs, Vol. XIII. $9^{\prime \prime} \times 6^{\prime \prime}$. Pp. 80. Bryn Mawr, Pa., I9I3.

Teubner's Text. Procopii Caesariensis Opera Omnia (J. Haury). Vol. III. $2.7^{\prime \prime} \times 4 \mathbf{z}^{\prime \prime}$. Pp. $x+395$. Leipzig: B. G. Teubner, I9I3. M. 7.50 .

Teuffel (W. S.) Römische Literatur (Dritter Band). Die Literatur von 96 nach Chr. bis zum Ausgange des Altertums. $9^{\prime \prime} \times 6^{\prime \prime}$. Pp. viii +579 . Leipzig: B. G. Teubner, I9r3. M. Io. 